\title{
Holocene History of a Portion of Northernmost Ellesmere Island
}

\author{
JOHN B. LYONS 1 and JAMES E. MIELKE2
}

\begin{abstract}
Radiocarbon dates and glaciological features of the Ward Hunt area along northernmost Ellesmere Island suggest the following chronology, which is consistent with world-wide climatic oscillations: 1) 10,000-4100 B.P.: deglaciation, and development of several marine levels, particularly one now $40 \mathrm{~m}$. above sea level, at $7500 \pm$ 300 B.P.; 2) 4100-2400 years B.P.: climatic deterioration, glacial readvance and formation of ice shelves; 3) 2400-1400 years B.P.: general climatic amelioration; development of dust ablation horizon on Ward Hunt Ice Shelf, glacial retreat; 4) 1400 B.P. - present: climatic deterioration, with renewed thickening of Ward Hunt Ice Shelf, and beginnings of growth of ice rises; the last-mentioned experienced maximum growth in the interval between 350-170 years ago; slight glacial readvance.

The isostatic rebound curve for northernmost Ellesmere Island differs from that of the Tanquary Fiord area 80 miles $(128 \mathrm{~km}$.) to the south because of differing Pleistocene ice thickenesses. We estimate these to average at least $600 \mathrm{~m}$. for the former area, and $1800 \mathrm{~m}$. for the latter.
\end{abstract}

RÉSUMÉ. Histoire holocène d'une portion de l'extrême-nord de l'ile d'Ellesmere. Les datations au radio-carbone et les caractéristiques glaciologiques de la région de Ward Hunt le long de l'extrême-nord de l'île d'Ellesmere suggèrent la chronologie suivante, qui s'accorde avec les oscillations climatiques mondiales: 1) de 10.000 à 4.100 A.P.; déglaciation, développement de plusieurs niveaux marins, particulièrement celui qu'on trouve maintenant à $40 \mathrm{~m}$ au-dessus du niveau de la mer, à $7.500 \pm 300$ A.P.; 2) de 4.100 à 2.400 A.P.; détérioration climatique, réavancée glaciaire et formation de plateformes de glace; 3) de 2.400 à 1.400 A.P.; amélioration climatique générale: développement d'un horizon de poussières d'ablation sur la barrière de Ward Hunt, retrait glaciaire; 4) de 1.400 A.P. à nos jours; détérioration climatique, nouvel épaississement de la barrière de Ward Hunt et début de la formation de dômes de glace: cette formation a atteint un maximum entre 350 et 170 A.P.; légère réavancée glaciaire.

La courbe du relèvement isostatique pour l'extrême-nord d'Ellesmere diffère de celle de la région du fiord de Tanquary à 80 milles $(128 \mathrm{~km})$ au sud, par suite des épaisseurs différentes de la glace pléistocène. Nous estimons celles-ci en moyenne à au moins $600 \mathrm{~m}$ pour la première et $1800 \mathrm{~m}$ pour la seconde.

РЕЗЮМЕ. История периода Голочена самой северной иасти острова Элсмпра. Радиоутлеродные данные и гляциологические особенности самой северной части острова Элсмира дают основания для следующей хронологии ивмененй, соответствующих общемировым колебаниям климата: 1) $10000-4100$ лет до Н.Э.: освобождение ото льда и развитие нескольких морских уровней, в частности уровня, который в настоящее время соответствует $40 \mathrm{M}$ выше уровня моря (7 $500 \pm 300$ до Н.Э.); 2) $4100-2400$ лет до Новой Эры: ухудшение климата, наступление льда и обравование ледяных уступов; 3) $2400-1400$ лет до Н.Э.: общее улучшение климата и отступление льда; 4) 1400 лет до Н.Э. по настоящее время: ухудшение климата и рост ледяных холмов, частичное возвращение льда.

Кривая изостатического отступления для наиболее северной части острова Элсмира отличается от соответствующей кривой для района фиорда Тәнквери, расположенного в 80 милях $(128 \mathrm{kм})$ к югу, из-за различия в толцинах льда в период Плейстоцена. По напим оценкам в первом случае толщина льда составляла в среднем по меньшей мере $600 \mathrm{M}$, а во втором случае $-1800 \mathrm{M}$.

1Department of Earth Sciences, Dartmouth College, Hanover, New Hampshire, U.S.A.

2Radiation Biology Laboratory, Smithsonian Institution, Washington, D.C., U.S.A. 


\section{INTRODUCTION}

An abundance of radiocarbon dates for the Arctic has prompted several recent summary papers (Farrand 1962; Andrews 1968, 1970a, 1970b, 1971; Grachev and Dolukanov 1970) in which it has been possible not only to show postglacial uplift curves for many different areas, but also to construct isobases of uplift for selected intervals of postglacial time. Such isobase maps (Andrews 1970b, 1971) as well as glaciological studies (Hattersley-Smith 1969; Blake 1970) demonstrate that Ellesmere Island supported a major ice cap during the Pleistocene, which was connected through a saddle covering the Queen Elizabeth Islands with a major accumulation centre along the northwest margin of Hudson Bay. In this paper we present some new radiocarbon dates from northern Ellesmere Island (Fig. 1, Table 1), relate these both to postglacial emergence and to the growth of the Ward Hunt Ice Shelf and contiguous ice rises, and attempt to make some approximations of the thickness of the Pleistocene ice covering Ellesmere Island.

\section{ORGANIC REMAINS: THEIR AGES AND RELATIONS TO GLACIAL AND ICE SHELF FEATURES}

A pelecypod-bearing (Table 1, SI-718) raised beach at 38 metres elevation is well developed along the north shore of Ward Hunt Island (Crary 1960; and Fig. 1). Along the east and southeasterly side of the island are less well preserved beaches which also carry pelecypods (SI-720).

The Ward Hunt Ice Shelf (Fig. 1) is actively being thrust onto the southeast and part of the southern end of Ward Hunt Island. Dorrer (1971) has found, by precise surveying, a northward movement of the ice shelf of $0.5 \mathrm{~m}$./year. Where the shelf touches ground a debris-laden ice ridge has formed. A rich biota is found both on the ridge and in the moat ice separating the ridge from Ward Hunt Island proper. Five species of pelecypods, 3 of gastropods, 2 of bryozoa, 1 of annelid, and 1 of echinoid may be found in the ice throughout this general area. Remarkably well-preserved siliceous sponges encrusted with sea worms and pelecypods are also relatively common in the moat ice. Skeletal to well-preserved remains of arctic cod (Arctogadus glacialis) have been found in the same area where the sponges occur. The ice which is being thrust ashore at the southeast edge of Ellesmere Island is basement ice (Lyons et al. 1971) largely of brackish-water origin. The downward encroachment of brackish water beneath an accreting ice shelf provides a plausible mechanism for the extinction of organic life on the arctic sea floor down to a depth slightly lower than the bottom of the Ward Hunt Ice Shelf (currently 43 metres).

The processes by which the dead biota may be incorporated into the basement ice are the following:

1) Thickening of the ice shelf until it touches ground and freezes onto the fossils; summer ablation at the surface combined with winter accretion at the bottom of the ice sheet sets up a mechanism whereby organic remains may be cycled upward through the ice;

2) Thrusting of the ice shelf toward shore, as at southeastern Ward Hunt Island; the net result is the same as in case 1; 


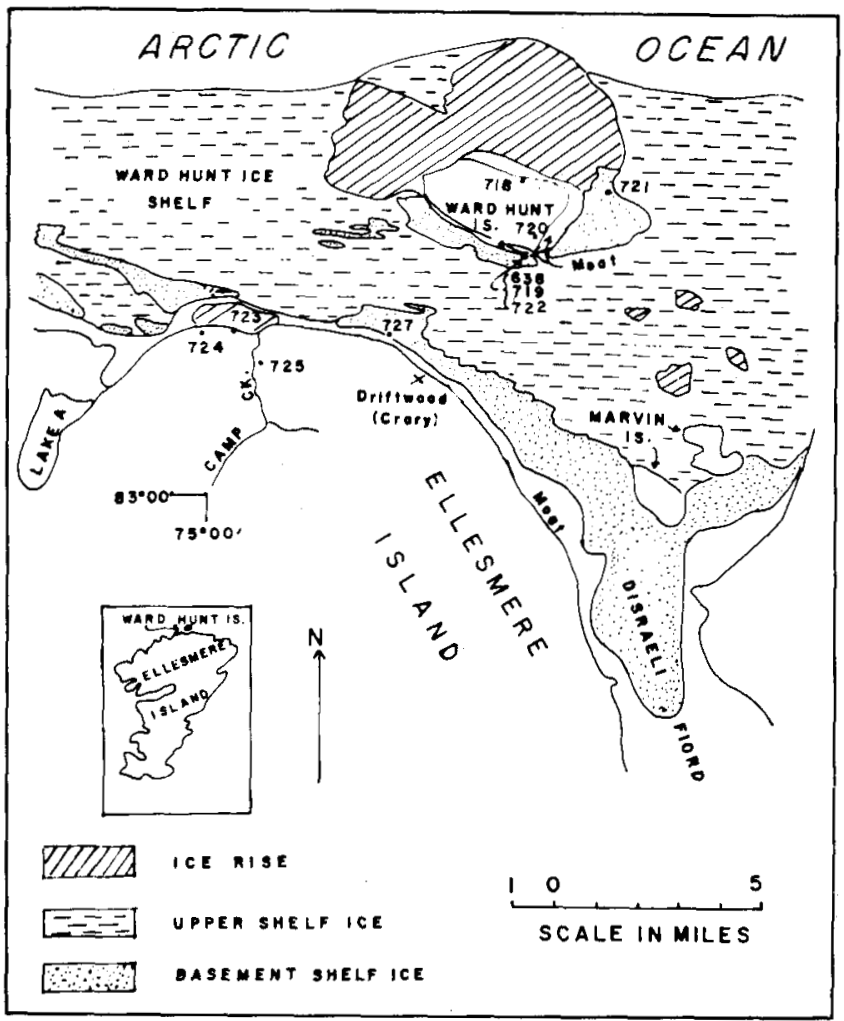

FIG. 1. Area contiguous to Ward Hunt Island, northern Ellesmere Island, showing locations of radiocarbon-dated samples.

3) Floating of dead fish or of fast ice (formed on the ocean floor because of permafrost conditions) to the underside of the accreting ice shelf.

Because of the processes by which the organic remains are entrapped and brought to the ice surface, it is very likely that the fossils will be older than the ice which encloses them. Some of our samples (SI-638, SI-719A, SI-719B, SI-721, SI-722, SI-727) represent ocean-floor biota which have been cycled upward through moat or basement ice in the manner we have described. These oceanfloor samples can have no significance in determining post-glacial rebound, but they appear to tell us a more interesting fact: there are probably no biota except swimming forms younger than approximately 3400 years beneath the Ward Hunt Ice Shelf. We propose that this may be a date for the final extinction of marine life beneath the original Ward Hunt Ice Shelf, and that the extinction was caused by brackish or fresh-water poisoning. Otherwise, there seems to be no logical explanation for the fact that 4 of the 6 undershelf samples (SI-638, SI-719B, SI-722, SI-727) show such a close correspondence in age, even though separated by a 5 -mile distance. The climatic record from Greenland (Dansgaard et al. 1969,1971 ) shows a cold period beginning 4100 years ago which is regarded by us as a possible date for the initiation of growth of the Ward Hunt Ice Shelf, and the beginning of the extinction of the sub-shelf fauna. We return to this point later in the paper.

Two of the more spectacular fauna emerging through the basement ice southeast of Ward Hunt Island are arctic cod (some with flesh still attached) and 
TABLE 1. Radiocarbon dates, Northern Ellesmere Island

\section{SI-638.}

Shell material in basement ice at southeast edge of Ward Hunt Island.

Same locality as SI-719, SI-722.

SI-718. Hiatella arctica Linné

Raised beach $38 \mathrm{~m}$, above sea level north side of Ward Hunt Island

(cf. Crary 1960, L248A, $7200 \pm 200$ ).

SI-719A.

$13,200 \pm 440$ B.P. 11,228 B.C.

Carbonate; calcilutite material encrusting siliceous sponges in ice at southeast edge of Ward Hunt Island. Same locality as SI-638, SI-722.

SI-719B.

$3400 \pm 140$ B.P.

Total organic material in sponge debris from ice at southeast edge 1528 B.C.

of Ward Hunt Island. Same locality as SI-638, SI-722.

SI-720. Hiatella arctica Linné

$5950 \pm 155$ B.P.

Raised beach (?) $5 \mathrm{~m}$. elevation on east side of Ward Hunt Island.

SI-721. Astarte, Vermetus

$6815 \pm 190$ B.P.

In basement ice at junction with shelf ice; 4865 B.C.

1 mile NNE of NE tip of Ward Hunt Island.

SI-722. Hiatella, Astarte, Vermetus 2040 B.C.

In basement ice at southeast edge of Ward Hunt Island.

Same locality as SI-638, SI-719.

SI-723. Hiatella arctica

Beneath Camp Creek Ice Rise from Till (?) being uncovered by ablation, 2825 B.C. at $5 \mathrm{~m}$. elevation.

\section{SI-724. Hiatella arctica}

Area immediately south of Camp Creek Ice Rise;

$10 \mathrm{~m}$. elevation.

SI-725. Hiatella arctica, Astarte, Vermetus

$1 / 2$ mile above mouth of Camp Creek

at $30 \mathrm{~m}$. elevation.

SI-727. Hiatella arctica, Astarte

$3680 \pm 100$ B.P.

In basement ice near Ellesmere Island 1730 B.C.

at south edge of ice shelf.

Shell samples (astarte, hiatella, limatula, vermetus) from the vicinity of Ward Hunt Island $\left(83^{\circ} \mathrm{N}\right.$., $74^{\circ}$ W.). Samples SI-638, SI-719A, SI-719B collected by Mielke; others by Lyons; radiocarbon analyses by Mielke.

NOTE: Pelecypods collected by Hattersley-Smith at the same locality as samples SI-638, SI-719, and SI-722 (Fig. 1) have a radiocarbon age of $4510 \pm 150$ year B.P. (Lowden and Blake 1970, p. 83; G.S.C. Sample 1025).

siliceous sponges up to a foot in maximum diameter. Crary $(1960$, p. 43) had reported a radiocarbon age of $400 \pm 150$ years B.P. on a sponge from this locality, so we have attempted to reproduce this result, and also to date the fish. 
For the latter we were unable to obtain a date, either on skeletons from this locality, or from a locality in basement ice close to Ellesmere Island (i.e. close to sample 727 of Fig. 1). Likewise, because of the extremely low amount of carbon in the sponges, we were unable to date an isolated sponge sample. However, the total organic material in the sponge and associated sediment yielded an age of $3400 \pm 140$ years (SI-719B). This, in conjunction with the dates of associated pelecypods, and the fact that our 5 samples from the ocean floor beneath the Ward Hunt Shelf (SI-638, SI-719B, SI-721, SI-722, SI-727) show no ages younger than 3400 years, makes us extremely dubious about the accuracy of the 400year-old date reported by Crary (1960). If correct, it would imply that sponges were the only invertebrates to re-establish themselves beneath the Ward Hunt Ice Shelf during the past several centuries, which seems possible, but hardly probable.

Northernmost Ellesmere Island has no well-preserved beaches. Despite this, pelecypods are not uncommon back from the present shoreline (cf. samples SI-723, SI-724, SI-725), and some fossils are enclosed in till(?). A conspicuous feature on the island is a well-preserved trimline at an elevation of 60 to 85 metres, coinciding at the mouth of one stream with a kame surface. These facts imply that at some time subsequent to Pleistocene deglaciation, and to the reestablishment of a marine fauna, Ellesmere Island experienced a glacial readvance. During this time glaciers debouching from the small valleys barely reached the shore of the Arctic Ocean where they came into contact with the Ward Hunt Ice Shelf. Basement ice nearest Ellesmere Island is deformed into anticlines and synclines with dips of up to 35 degrees, implying deformation by glacial push. It is noteworthy that at the present time glacial push appears to be deforming the Milne Ice Shelf, 65 miles south-southwest of Ward Hunt Island (G. Hattersley-Smith, oral communication, 1972). Because the Ellesmere fossils fit so closely on a glacial rebound curve (Fig. 2), we also conclude that they have not been moved far from their original sites of deposition, probably because the glacier termini were nearby.

Hattersley-Smith (1969) has shown that in the north-central portion of Ellesmere Island a strong glacial readvance has taken place within the last 4000 years. It is almost a certainty that this readvance is identical to that along the north shore of Ellesmere Island. Reference to the climatic record preserved in the Greenland ice cores (Dansgaard et al. $(1969,1971)$ ) leads to the conclusion that the reactivated glaciers on Ellesmere Island commenced their growth approximately 4100 years ago. This glacial cycle very probably coincides with the initiation of growth of ice shelves along parts of the north coast of Ellesmere Island.

Blake (1972) has reviewed the now-extensive radiocarbon dates on driftwood on the Queen Elizabeth Islands, pointing out that such logs first appear 8500 to 8000 years ago, and that they become abundant during the 6500 to 4500 B.P. time span. Their abrupt decrease during 4500 to 500 B.P. implies (Blake, 1972) an onset of more severe ice conditions and the development of ice shelves especially along the north coast of Ellesmere Island. It is interesting that Blake's chronology is in good agreement with the conclusions of Dansgaard et al. (1969, 


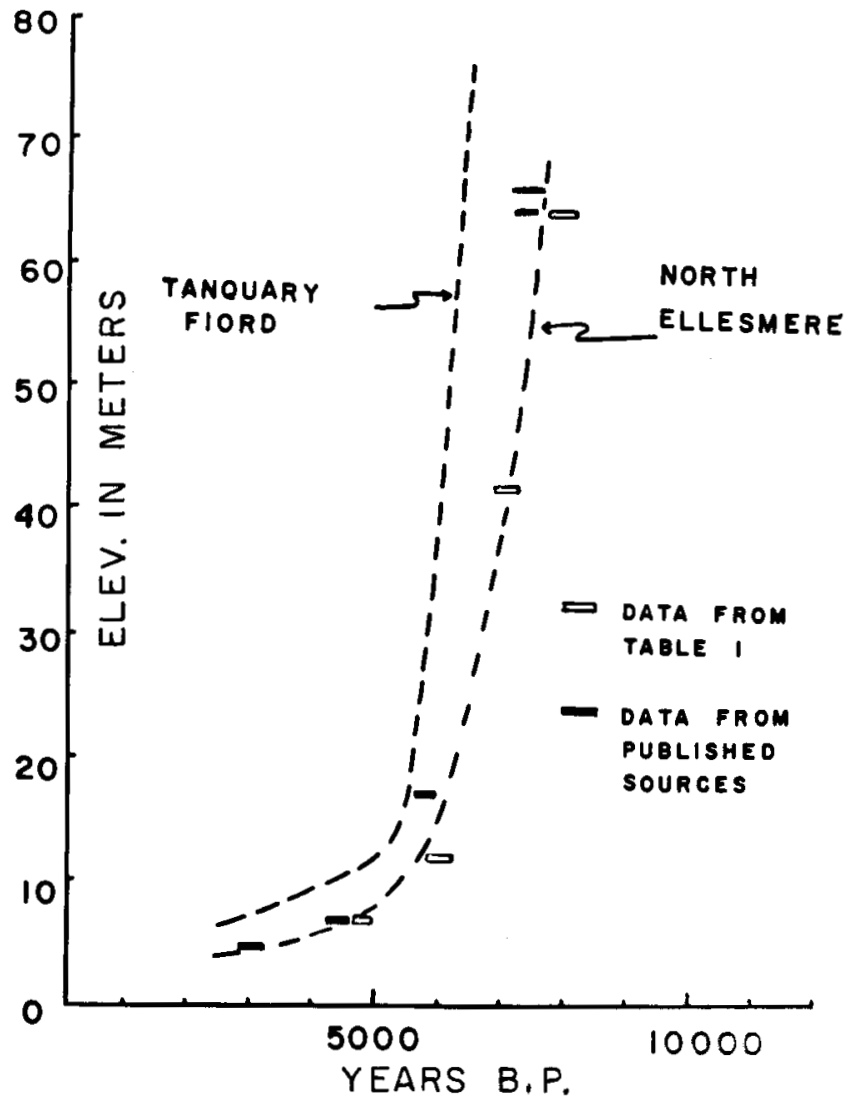

FIG. 2. Comparative isostatic rebound curves for the north coast of Ellesmere Island and for the Tanquary Fiord area of Ellesmere Island.

1971) for Greenland, and Hattersley-Smith (1969) for Ellesmere Island; there can be no question that a sudden climatic deterioration began 4500 to 4100 years ago throughout much of the Arctic.

With respect to the Ward Hunt Ice Shelf, however, Crary $(1960$, p. 43) reported four samples of driftwood from near the mouth of Disraeli Fiord (Fig. 1) all from the same locality back of the shelf, and not more than 3 metres above sea level. Their radiocarbon ages range from 3000 to 6120 years. Subsequently, Mielke and Long (1969, p. 176) published three additional dates $(>35,000$, $<35,000$, and $6280 \pm 140$ years B.P.) on driftwood collected during 1967 by J. E. Keys not far from the Crary locality (Fig. 1). These dates may mean, as Crary (1960) concluded, that the Ward Hunt Ice Shelf did not entirely close over until 3000 years ago. Alternatively, it could show that the shelf had formed earlier, but partly deteriorated 3000 years ago (cf. Dansgaard et al., 1971, Fig. 7), or that a channel along the edge of the ice shelf may have allowed the youngest logs to drift in, possibly along a moat such as the 200 -metre wide moat (Fig. 1) now separating the shelf from Ellesmere Island. As Hattersley-Smith (written communication, 1972) has pointed out, the ages of the youngest driftwood ( $3000 \pm 200$ B.P.; Crary L 254 D) and of the youngest marine shells (3390 \pm 130 B.P. Table 1) provide a near overlap at 3200 B.P. and some contrary evidence 
to the idea that the Ward Hunt Ice Shelf was in existence at that time. In our summary diagram (Fig. 3) of post-glacial chronology along northern Ellesmere Island, we have indicated an initiation of ice shelf development commencing approximately 4100 years B.P., but admit that the evidence is not conclusive for the Ward Hunt Ice Shelf, and that any of the alternatives we have cited may be valid.

\section{POST-GLACIAL REBOUND}

Enough radiocarbon dates are now available for northern Ellesmere Island to fix, rather closely, a rebound curve for the last 7800 years (Fig. 2). In addition to those dates in Table 1 which are significant for post-glacial upwarp, we have used the following data from Crary $(1960$, p. 43$)$ :

1) Driftwood $-3000 \pm 200$ years -3 metres elevation; Disraeli Fiord, back of Ward Hunt Ice Shelf.

2) Hiatella arctica $-7200 \pm 200$ years -38 metres elevation; this is from the same locality as our sample SI-718, which dates at $7750 \pm 150$ years.

3) Mollusc shells $-7200 \pm 250$ years -40 metres elevation (Christie 1967, p. 19); west side of McClintock Bay.

A series of density-stratified lakes along the north coast of Ellesmere Island (Hattersley-Smith et al. 1970) was sampled in 1969, and radiocarbon dates determined by Mielke on the bicarbonate in solution in the deeper saline waters. Results are being reported elsewhere. One of the lakes is situated 10 miles southwest of Ward Hunt Island, behind the ice shelf. Its radiocarbon age is $4455 \pm 105$ years, and its outlet is at 5 metres elevation. This point is also shown in Fig. 2. These 9 radiocarbon dates for northern Ellesmere Island have been used to define the rebound curve of Fig. 2; the elevation of each point has been corrected for eustatic rise of sea level, and therefore differs from the value listed in Table 1.

In the Tanquary Fiord area of Ellesmere Island, 80 miles south of the coast, Hattersley-Smith and Long (1967) on the basis of 7 radiocarbon dates have constructed an uplift curve somewhat different from ours (cf. Fig. 2). Their curve extends back to 6500 years and covers elevations up to 76 metres.

The difference in the 2 rebound curves for Ellesmere Island must relate to differences in the Pleistocene ice thicknesses at these two points. The distribution of erratics shows that Ward Hunt Island (elevation $\sim 400$ metres) was overridden by the Pleistocene ice cap, and we have found erratics along northern Ellesmere Island at elevations up to 600 metres. A fiord extends from Disraeli Fiord between Ward Hunt and Ellesmere Islands, attaining depths of 900 metres in this area (Crowley 1961). The fiord must have been ice-filled at the time Ward Hunt Island was overridden. We consider, therefore, that 600 metres is a conservative estimate of maximum Pleistocene ice cap thickness at northern Ellesmere Island. Using this as one datum point, taking the generally accepted value of 1 bar as the maximum shearing stress at the bottom of an ice sheet, neglecting the slope and roughness of the bottom of this ice sheet, but assuming that it is grounded because of the deep fiord, the following approximations may be used: 


$$
\begin{aligned}
& \overline{\mathrm{P}}=1 / 2 \text { pgh } \\
& \tau \mathrm{X}=\overline{\mathrm{P}} \mathrm{h}
\end{aligned}
$$

where $\overline{\mathrm{P}}=$ average pressure midway through an ice sheet; $\mathrm{h}=$ thickness; $\mathrm{x}=$ distance from ice-cap edge to the point where thickness is measured; $\tau=$ shear stress $($ max. $) \cong 1$ bar; $g=$ acceleration of gravity; $\rho=$ density. From (1) and (2) we calculate that the edge of the ice cap extended at least $16 \mathrm{~km}$. (10 miles) north of Ward Hunt Island (Fig. 1), and that the thickness of ice at the Ellesmere divide $127 \mathrm{~km}$. ( 80 miles) to the south was approximately $1.8 \mathrm{~km}$. (1.12 miles). These are not unreasonable values; they would be quite consistent with the different rebound curves shown in Fig. 1.

\section{POST-GLACIAL CHRONOLOGY}

The coincidence of the climatic record for the Greenland and Antarctic ice caps (Johnson et al. 1972) and the fact that these records also agree with data culled from compilations of world-wide radiocarbon dates (Bray 1970) imply a synchroneity of climatic oscillations that must be represented during Holocene time in the sequence of events we have described on northernmost Ellesmere

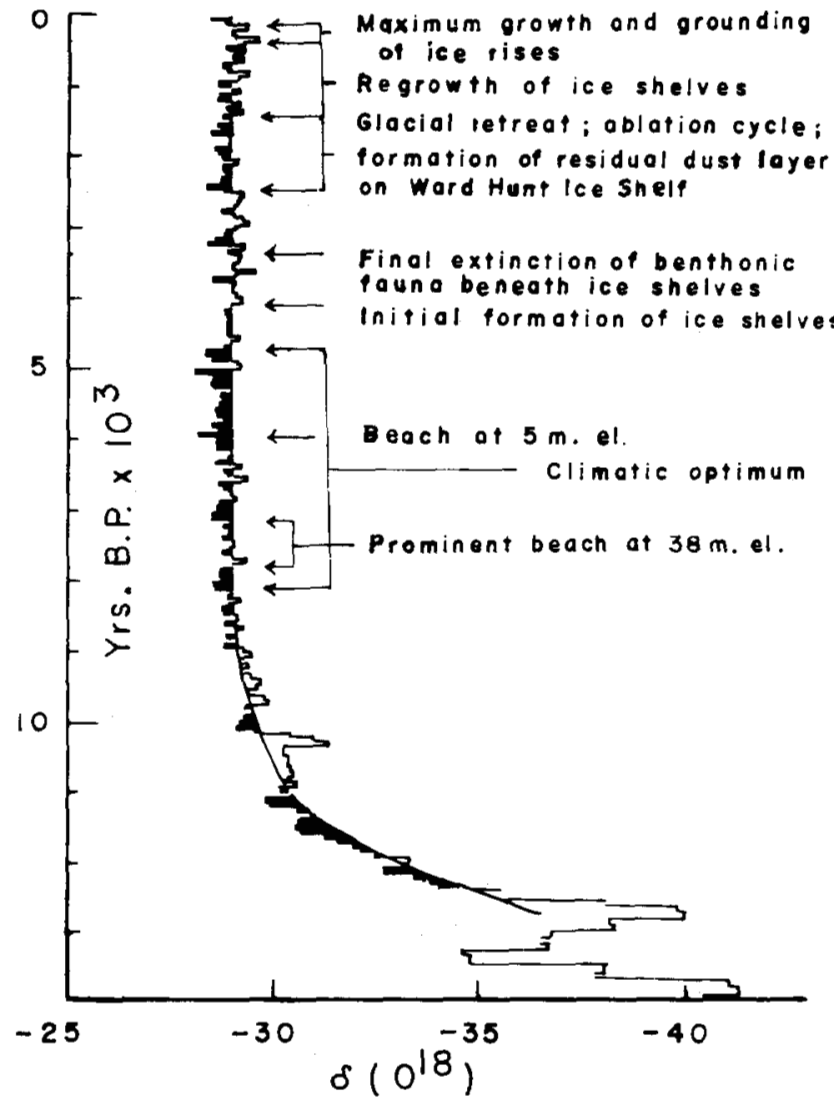

FIG. 3. Interpretation of the Holocene history of northernmost Ellesmere Island and its probable correlation with the climatic record preserved in the Greenland ice cores. 
Island. Accepting the Greenland and Antarctic chronologies as key points, we have shown Fig. 3 (modified from Dansgaard et al. 1969) what we now consider to be the best reconciliation of the data for northernmost Ellesmere Island, particularly as it relates to the growth and development of ice shelves and glaciers. Although a 3000-year date has generally been accepted for the initial time of formation of the Ward Hunt Ice Shelf (Crary 1960; Hattersley-Smith 1969; Lyons et al. 1971) there now appear to be reasons why an older date $(\sim 4100$ years B.P.) may be postulated.

Two points we have not touched upon are: 1) the age of a dust ablation zone separating the basement and upper ice of the Ward Hunt Ice Shelf, and 2) the ages of the ice rises in and near the Ward Hunt Ice Shelf. The radiocarbon dates on the dust horizon (Crary 1960) are so variable (480-5830 years B.P. for 6 samples; Crary 1960, p. 41-42) as to be almost meaningless, but Crary's shrewd deduction of 1600 years seems to be not far off from a general ablation period extending from 2400-1400 B.P. in the Greenland cores. An analysis of thermal profiles through the Ward Hunt Ice Shelf and contiguous ice rises (Lyons et al. 1972) has also allowed us to calculate that the time of maximum growth, and of grounding, of the ice rises occurred 250-350 years ago, dates which fall within the "Little Ice Age" cold cycle which extended from 350-170 years ago.

There is no reliable information on northernmost Ellesmere Island which closely fixes the transition from the Pleistocene to the Holocene, except that it must be earlier than 7800 years B.P. (sample SI-718). From Dansgaard et al. 1971, Fig. 6), we infer an age of 10,000-13,000 years B.P. as the most likely transition period.

\section{ACKNOWLEDGEMENTS}

We are grateful to G. Hattersley-Smith for his review of an earlier draft of this manuscript, but the interpretations of this paper do not necessarily imply his agreement. Weston Blake, Jr. of the Canadian Geological Survey kindly furnished a preprint of his paper on radiocarbon-dated driftwood in the Queen Elizabeth Islands, and other data. We are also indebted to the Canadian Defence Research Board, U.S. Army Cold Regions Research and Engineering Laboratories, and the Arctic Institute of North America for logistic and financial support of this research.

\section{REFERENCES}

ANDREws, J. T. 1968. Postglacial rebound in Arctic Canada: similarity and prediction of uplift curves. Canadian Journal of Earth Sciences, 5:39-47.

1970a. Present and postglacial rates of uplift of glaciated northern and eastern North America derived from postglacial uplift curves. Canadian Journal of Earth Sciences, 7:703-15.

1970b. A geomorphological study of postglacial uplift with particular reference to

Arctic Canada. Institute of British Geographers Monograph Series No. 2. 157 pp.

1971. Comparison of elevations of archeological sites and calculated sea levels in Arctic Canada. Arctic, 24:210-228.

BLAKE, W., JR. 1970. Studies of glacial history in Arctic Canada. I Pumice radiocarbon-dates and differential postglacial uplift in the eastern Queen Elizabeth Islands. Canadian Journal of Earth Sciences, 7:634-64. 
1972. Climatic implications of radiocarbon-dated driftwood in Queen Elizabeth Islands, Arctic Canada. In: Y. Vasari, H. Hyvarinen and S. Hicks (eds.) Climatic Changes in Arctic Areas During the Last 10,000 Years. Oulu, Finland: University of Oulu Press, 511 pp. pp. 77-104.

BRAY, J. R. 1970. Temporal patterning of post-Pleistocene glaciation. Nature, 228:353.

CHRISTIE, R. L. 1967. Reconnaissance of the surficial geology of northernmost Ellesmere Island, Arctic archipelago. Geological Survey of Canada Bulletin 138, $50 \mathrm{pp}$.

CRARY, A. P. 1960. Arctic ice island and ice shelf studies, Part II. Arctic, 13:32-50.

CROWLEY, F. A. 1961. Gravity observations along the northern coast of Ellesmere Island. Air Force Cambridge Research Laboratories, G.R.D. Research Notes, no. 53.7 pp.

DaNsGaARD, W., s. J. JoHNSEN, J. MOLleR and C.C. LANGWAY. 1969. One thousand centuries of climatic record from Camp Century on the Greenland ice sheet. Science, 166:377-80.

DANSGAARD, W., S. J. JOHNSEN, H. B. CLAUSEN and C. C. LANGWAY, JR. 1971. Climatic record revealed by the Camp Century ice core. In: K. K. Turekian, ed., The Late Cenozoic Glacial Ages. Yale University Press. pp. 37-56.

DORRER, E. 1971. Movement of the Ward Hunt Ice Shelf, Ellesmere Island, N.W.T., Canada. Journal of Glaciology, 10:211-26.

FARRAND, W. R. 1962. Postglacial uplift in North America. American Journal of Science, 260:181-99.

GRACHEv, A. F. and P. M. DOLUKANov. 1970. Postglacial crustal uplift in Canada and Fennoscandia from radiocarbon dating. Baltica, 4:297-312. (In Russian, with English and German abstracts.)

HATTERSLEY-SMITH, G. 1969. Glacial features of Tanquary fiord and adjoining areas of northern Ellesmere Island, N.W.T. Journal of Glaciology, 8:23-50.

HATTERSLEY-SMITH, G., J. R. KEYS, H. SERSON and J. E. MIELKE. 1970. Density stratified lakes in northern Ellesmere Island. Nature, 225:55-56.

HATTERSLEY-SMITH, G. and A. LONG. 1967. Postglacial uplift at Tanquary fiord, Northern Ellesmere Island, Northwest Territories. Arctic, 20:255-60.

JOHNSEN, S. J., W. DANSGAARD, H. B. CLAUSEN, and C. C. LANGWAY. 1972. Oxygen isotope profiles through the Antarctic and Greenland ice sheets. Nature, 235:429-34.

LOWDEN, J. A. and W. BLAKE. 1970. Geological Survey of Canada Radiocarbon Dates IX. Radiocarbon, 12:46-86.

LYONS, J. B., s. M. SAVIN and A. J. TAMBURI. 1971. Basement ice, Ward Hunt Ice Shelf, Ellesmere Island, Canada. Journal of Glaciology, 10:93-100.

LYONS, J. B., R. H. RAGLE and A. J. TAMBURI. 1972. Growth and grounding of the Ellesmere ice rises. Journal of Glaciology, $11: 43-52$.

MIELKE, J. E. and A. LONG. 1969. Smithsonian Institution Radiocarbon Measurements V. Radiocarbon, $11: 163-82$. 